\title{
Strength and Durability Study of Concrete Structures Using Aramid-Fiber-Reinforced Polymer
}

\author{
Rajashekhar Siddappa Talikoti ${ }^{1}$ and Sachin Balkrishna Kandekar ${ }^{2, *(1)}$ \\ 1 Sandip Institute of Engineering and Management, Nashik 422213, MS, India; rstalikoti@gmail.com \\ 2 Late G N Sapkal College of Engineering, Nashik 422212, MS, India \\ * Correspondence: sachin.kandekar@avcoe.org; Tel.: +91-98-9000-4028
}

Received: 11 October 2018; Accepted: 18 January 2019; Published: 26 January 2019

check for updates

\begin{abstract}
Fiber-reinforced polymer (FRP) is an important material used for strengthening and retrofitting of reinforced concrete structures. Commonly used fibers are glass, carbon, and aramid fibers. The durability of structures can be extended by selecting an appropriate method of strengthening. FRP wrapping is one of the easiest methods for repair, retrofit, and maintenance of structural elements. Deterioration of structures may be due to moisture content, salt water, or contact with alkali solutions. Using FRP, additional strength can be gained by structural elements. This paper investigates the durability of aramid-fiber-wrapped concrete cube specimens subjected to acid attack and temperature rise. The study focuses on the durability of aramid-fiber-wrapped concrete by considering the compressive strength parameter of the concrete cube. Concrete cubes are prepared as specimens with a double wrapping of aramid fibers. Diluted hydrochloric acid solution is used for immersion of specimens for curing periods of 7, 30, and 70 days. The aramid-fiber wrapping reduces weight loss by $40 \%$ and improves compressive strength by $140 \%$. In a fire resistance test, the specimens were kept in a hot air oven at a temperature of $200^{\circ} \mathrm{C}$ at different time intervals. Even after fire attack, weight loss in specimens reduced by $60 \%$, with about $150 \%$ enhancement in compressive strength due to aramid fiber.
\end{abstract}

Keywords: aramid fiber; durability; fiber-reinforced polymer; repair; retrofit; wrapping

\section{Introduction}

Fiber-reinforced polymers are extensively used in the strengthening and retrofitting of structurally deficient infrastructures. The polymer is typically an epoxy, vinyl-ester, or polyester thermosetting plastic, with a phenol formaldehyde resin. When two or more materials with different physical and chemical properties come together, they form such composites. FRP materials are of high strength-to-weight ratios and are therefore used in seismic retrofit, since an increase in weight will lead to an increase in seismic force.

Concrete is the most extensively used building material in the construction industry, but it faces some problems, such as damage from earthquakes and cracking due to shrinkage and expansion. Due to these problems, concrete suffers from moisture attack, resulting in corrosion of steel reinforcement and loss of structural strength. Such damage can be repaired using FRP materials. Structures can also be strengthened to accommodate changes in load variation or code revisions.

There is an insufficient database on FRP materials, which makes it difficult for civil engineers and practitioners to use FRP materials on a regular basis. Composites of FRP are manufactured from endless fibers (carbon, glass, and aramid) inserted in the matrix of thermosetting resins of epoxy, vinyl ester, or polyester. The resins bind these fibers together to transfer the load in between (Frigione et al. [1]). Karbhari et al. [2] studied the durability of FRP as internal reinforcement for external strengthening, seismic retrofit, bridge decks, structural profiles, and panels. FRP wrapping is 
very easy to handle and can be installed rapidly. Proper attention is required for the bond between the FRP material and the concrete surface. Compared with steel plates, FRP is more durable, has no risk of corrosion, and is highly resistant to the aggressive environment, as investigated by Nur Hajarul Falahi et al. [3]. Fossetti and Minafo [4] investigated the compressive strength of clay brick masonry column having Basalt Fiber Reinforced Cementitious Matrix (BFRCM) and steel wire collaring as reinforcement. Installation of FRP is one of the easiest retrofitting techniques due to its high speed and less complex nature. It also creates fewer disturbances to the occupants. FRP avoids chemical attack and temperature rises, reduces permeability, and improves strength.

\subsection{Strength and Durability of Concrete Structures Using FRP}

Concrete is one of the key materials used in construction over the years. Researchers are working on the durability of concrete to save existing structures. Durability can be improved by strengthening existing structures using various techniques. FRP wrapping is one method of strengthening used widely nowadays. Strength and durability studies of FRP under acid attack and temperature changes provide a good insight into the superiority and benefits of FRP in concrete construction, as well as its limitations. Generally, FRP is of high strength, providing good resistance to chemical attack and corrosion in extreme weather conditions. Performance of FRP is affected by its mechanical properties, method of fabrication, and the types of material used. When structures are exposed to acid attack and temperature changes, the durability and high resistance of FRP in an aggressive environment make it superior compared to conventional concrete.

Due to extensive use of FRP in the construction industry, its durability is an important factor in the selection of proper material for the purpose of strengthening. Anandakumar et al. [5] studied the durability of basalt-fiber-reinforced polymer (BFRP) for retrofitting of RC piles. BFRP was wrapped around concrete cubes and tested with acid immersion and for fire resistance. Hashim et al. [6] considered the durability of material at two locations. Firstly, the material used has to satisfy durability requirements, and secondly, so does the bond interface between FRP material and concrete surface. Some studies are limited to degradation of interfacial bonding in between CFRP and concrete due to environmental exposure. Choi et al. [7] worked on the durability of CFRP material affected by environmental changes. Same materials behave in different fashions under different environmental conditions. Accordingly, relative assessment was done to investigate a new technique for finding the durability of CFRP material designed for the same application.

According to Zaman et al. [8], FRP materials are vulnerable to heat and moisture when subjected to changes in the environment. The reaction of FRP against heat is one of the important factors as far as temperature effects are concerned. Zeng-Zhu Zhu et al. [9] investigated the durability performance of glass-fiber-reinforced polymer (GFRP) and carbon-fiber-reinforced polymer (CFRP) under conditions of humidity, temperature rise, wet and dry cycle, freeze-thaw effect, ultraviolet radiation, and natural exposure. Byars et al. [10] discussed the durability of FRP material in an aggressive environment. Various types of fiber, such as glass fiber, carbon fiber, and aramid fibers were taken into consideration. The effect of moisture, acid attack, and temperature changes on properties of fibers is elucidated. Hamad et al. [11] and Hawileh et al. [12] investigated the mechanical behavior of FRP under elevated temperature. Material can lose its strength as a result of a rise in temperature. Use of FRP can prohibit such losses in tensile strength caused by elevated temperature. Also, the effect of a temperature rise on epoxy adhesive is taken into consideration. According to Hawileh et al. [12], FRP material fails at elevated temperatures with different modes. At temperatures of 100 to $150^{\circ} \mathrm{C}$, it fails in brittle rupture. When the temperature is further raised up to 200 to $250{ }^{\circ} \mathrm{C}$, epoxy adhesive softens. At $300{ }^{\circ} \mathrm{C}$, the adhesive gets burned and the specimen fails.

\subsection{Aramid-Fiber-Reinforced Polymer}

The aramid fiber originates from aromatic polyamide (aramids) and depends on paraphenylene teraphthalamide, which introduces an amide group and benzene rings into polyamide molecules 
together. Due to strong inter-chain bonding and a high level of crystallization, modulus and tenacity of these fibers are very high (Chen and Zhou [13]). In aramid fibers, $85 \%$ of amide linkages are directly attached to two aromatic rings. These fibers have 5-10\% more mechanical properties than synthetic fibers. Such fibers are typically used in composite structures for application in aircraft, marine and automobile, rope for offshore oil rigs, and bulletproof vests. Aramid fibers are abrasion-resistant under cyclic loading. They are five times stronger than steel and also heat-resistant (Jassal and Ghosh [14]). The tensile strength is between 2400 and $3600 \mathrm{~N} / \mathrm{mm}^{2}$ with percentage elongation of $2.2 \%$ to $4.4 \%$. The tensile modulus is 60 to $120 \mathrm{GPa}$. Granata and Parvin [15] worked on Kevlar fiber, which is a type of aramid fiber for the strengthening of the beam-column joint. Shell chemical epoxy was used as an adhesive in this study.

Pereira and Revilock [16] used an aramid fiber named Kevlar fabric of tensile strength 55\% greater than E-glass fiber and shear strength $180 \%$ stronger than E-glass fiber. The bulk density (mass per unit of volume) and linear density (mass per unit of length) of the fabric are $1.44 \mathrm{~g} / \mathrm{cm}^{3}$ and $1.656 \times 10^{3} \mathrm{~g} / \mathrm{cm}^{3}$, respectively. A woven bidirectional aramid fabric of plain weave style is used in this study. The areal weight of this fiber is $300 \mathrm{~g} / \mathrm{m}^{2}$. The thickness of the dry fabric is $0.25 \mathrm{~mm}$. Figure 1 shows the texture of aramid fiber.

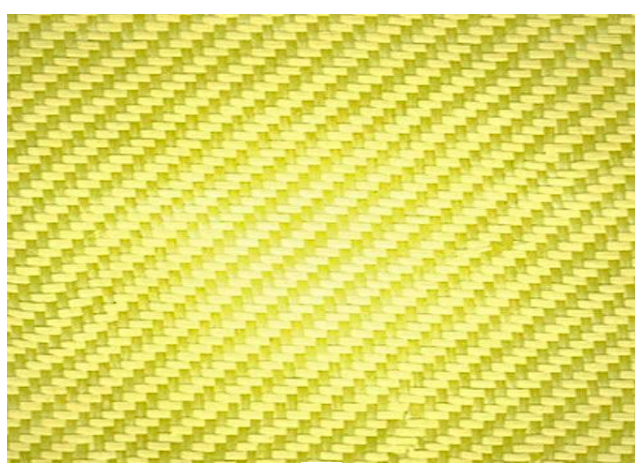

(a)

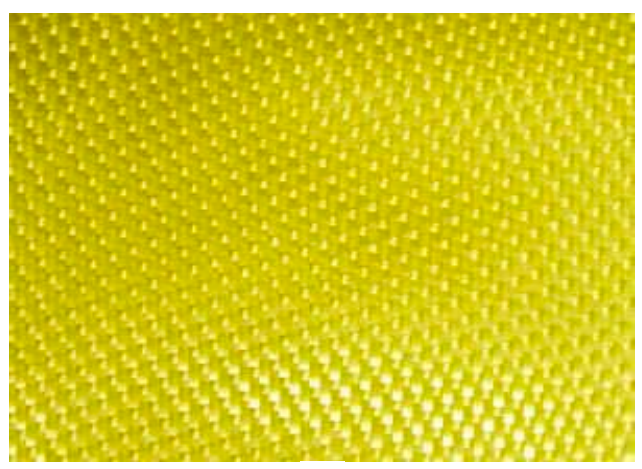

(b)

Figure 1. Aramid-fiber-reinforced polymer. (a) Front side; (b) Back side.

This paper studies the effect of aramid-fiber-reinforced polymer wrapping on the strength of a concrete cube subjected to acid attack and rise in temperature. Comparisons are made between wrapped specimens and unwrapped (controlled) specimens. Results are drawn in terms of reduction in weight loss and improvement in compressive strength due to aramid-fiber wrapping. In structures, several members sustain compressive loads. As per IS 456-2000, design stress is derived from the compressive strength of cube. For design purposes, the compressive strength of concrete in the structure shall be assumed to be 0.67 times its characteristic strength, considering shape and size effect. Concrete is strong in compression and its strength can be further improved against chemical and fire attack using FRP.

\section{Methodology}

A concrete mix design is prepared for M30-grade concrete. The code used for concrete mix design is IS 10262-2009 “Concrete Mix Proportioning-Guidelines". Table 1 shows the design mix proportion for M30-grade concrete.

Table 1. Proportions of design mix.

\begin{tabular}{ccccc}
\hline Description & Cement & Fine Aggregate & Coarse Aggregate & Water \\
\hline Design mix proportions & 1 & 2.14 & 3.54 & 0.45 \\
\hline Materials quantities $\left(\mathrm{kg} / \mathrm{m}^{3}\right)$ & 350 & 749.00 & 1239 & 157.50 \\
\hline
\end{tabular}


As FRP material is to be wrapped around concrete cubes, the surface characteristics of the concrete are very important in order to furnish proper bonds in the contact area. The fabric material is cut as per the requirement of the area to be covered. Cement paste, if any, is removed and cubes are coated with a mixed proportion of resin and hardener as 100:30. The properties of the resins and hardeners are shown in Tables 2-4. Finally, the aramid fiber is wrapped around cubes. Entrapped air bubbles between the fabric and the surface of the cube specimen, if any, are removed.

Table 2. Properties of HINPOXY C resin.

\begin{tabular}{ccc}
\hline Characteristic & Unit & Specification \\
\hline Viscosity at $25^{\circ} \mathrm{C}$ & $\mathrm{mPas}$ & $9000-12,000$ \\
Epoxy content & $\mathrm{g} / \mathrm{eq}$ & $185-192$ \\
Density at $25^{\circ} \mathrm{C}$ & $\mathrm{g} / \mathrm{cc}$ & $1.15-1.20$ \\
Flash point & ${ }^{\circ} \mathrm{C}$ & $>200$ \\
Storage & Years & 3 \\
\hline
\end{tabular}

Table 3. Properties of HINPOXY C hardner.

\begin{tabular}{ccc}
\hline Characteristic & Unit & Specification \\
\hline Viscosity at $25^{\circ} \mathrm{C}$ & $\mathrm{mPas}$ & $<50$ \\
Density at $25^{\circ} \mathrm{C}$ & $\mathrm{g} / \mathrm{cc}$ & $0.94-0.95$ \\
Flash point & ${ }^{\circ} \mathrm{C}$ & $>123$ \\
Storage & Years & 1 \\
\hline
\end{tabular}

Table 4. User guide.

\begin{tabular}{cc}
\hline Properties of System & Limit \\
\hline Mix ratio (HINPOXY C resin:HINPOXY C hardener) & $100: 30(w / w)$ \\
Gel time at $30^{\circ} \mathrm{C}(100 \mathrm{~g})$ & $120 \mathrm{~min}$ \\
Full cure time at $30{ }^{\circ} \mathrm{C}$ & $24 \mathrm{~h}$ \\
Impact strength at $30^{\circ} \mathrm{C}, \mathrm{kg} / \mathrm{cm}(\mathrm{ISO} 6272)$ & $60-70$ \\
\hline
\end{tabular}

\subsection{Tests on Fiber-Reinforced Polymer}

\subsubsection{Acid Resistance Test}

A total of 18 concrete cube specimens were cast with M30-grade concrete. Nine are conventional concrete cubes (controlled specimens) and the remaining nine cubes are double-wrapped with aramid fiber. These specimens are cured in water for 28 days. After curing, these specimens are dried out for $36 \mathrm{~h}$ and their initial weight is taken. After this, the specimens are immersed in $2 \%$ diluted hydrochloric acid $(\mathrm{HCl})$ acid solution. Casting program of the cube is done as per Table 5. The properties of diluted $\mathrm{HCl}$ solution are shown in Table 6.

Table 5. Casting of cubes in $2 \%$ diluted $\mathrm{HCl}$ solution.

\begin{tabular}{cccc}
\hline \multirow{2}{*}{ Description of Specimen } & \multicolumn{3}{c}{ Specimens Immersed in $\mathbf{H C l}$ Acid Solution-Duration } \\
\cline { 2 - 4 } & $\mathbf{0}$ days & $\mathbf{7}$ days & $\mathbf{3 0}$ days \\
\hline Controlled specimens & 3 & 3 & 3 \\
\hline Double-wrapped aramid fiber specimens & 3 & 3 & 3 \\
\hline
\end{tabular}


Table 6. Properties of the diluted acid solution.

\begin{tabular}{cc}
\hline Properties of Diluted HCl (Acid Strength 2\%) & Value \\
\hline $\mathrm{pH}$ value & 1.54 \\
\hline Total dissolved solids (TDS) in parts-per-million (ppm) & 54.5 \\
\hline
\end{tabular}

These specimens were removed from the solution as per the times given in Table 5 and the final weight of the specimens was noted. All the specimens were tested for compressive load as per IS 516-1959. See Figure 2 for compressive strength tests on the specimens. Comparisons were drawn for controlled specimens and double-wrapped aramid fiber specimens in terms of weight loss and strength loss, as shown in Table 7. Comparative charts are shown in Figures 3 and 4.

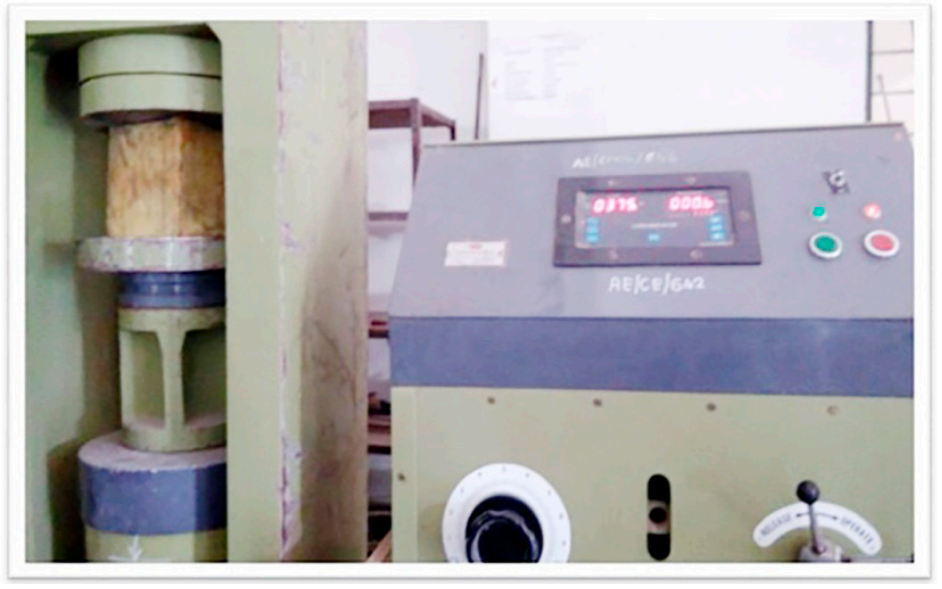

Figure 2. Compressive strength test.

Table 7. Acid resistance test results.

\begin{tabular}{cccccccccccc}
\hline \multicolumn{2}{c}{ Description } & \multicolumn{3}{c}{ After 7 days } & \multicolumn{3}{c}{ After 30 days } & \multicolumn{3}{c}{ After 70 days } \\
\hline \multirow{3}{*}{$\begin{array}{c}\text { Controlled } \\
\text { specimens }\end{array}$} & Cube & 1 & 2 & 3 & 1 & 2 & 3 & 1 & 2 & 3 \\
\cline { 2 - 11 } & Initial weight (g) & 8485 & 8440 & 8386 & 8660 & 8580 & 8625 & 8485 & 8505 & 8435 \\
\cline { 2 - 11 } & Final weight (g) & 8470 & 8429 & 8405 & 8639 & 8555 & 8638 & 8453 & 8467 & 8460 \\
\cline { 2 - 11 } & Weight loss (\%) & 0.18 & 0.13 & 0.23 & 0.24 & 0.29 & 0.27 & 0.38 & 0.33 & 0.30 \\
\cline { 2 - 11 } & $\begin{array}{c}\text { Compressive } \\
\text { strength (MPa) }\end{array}$ & 35.20 & 35.06 & 34.94 & 34.88 & 34.80 & 34.23 & 34.62 & 34.35 & 33.86 \\
\hline $\begin{array}{c}\text { Double-wrapped } \\
\text { aramid fiber } \\
\text { specimens }\end{array}$ & Initial weight (g) & 8432 & 8501 & 8465 & 8603 & 8600 & 8592 & 8550 & 8585 & 8556 \\
\cline { 2 - 11 } & Final weight (g) & 8428 & 8499 & 8470 & 8495 & 8591 & 8600 & 8539 & 8572 & 8566 \\
\cline { 2 - 10 } & Weight loss (\%) & 0.05 & 0.02 & 0.06 & 0.09 & 0.10 & 0.09 & 0.13 & 0.15 & 0.12 \\
\cline { 2 - 10 } & $\begin{array}{c}\text { Compressive } \\
\text { strength (MPa) }\end{array}$ & 51.11 & 51.02 & 50.80 & 50.31 & 49.37 & 49.46 & 49.28 & 48.71 & 48.80 \\
\hline
\end{tabular}




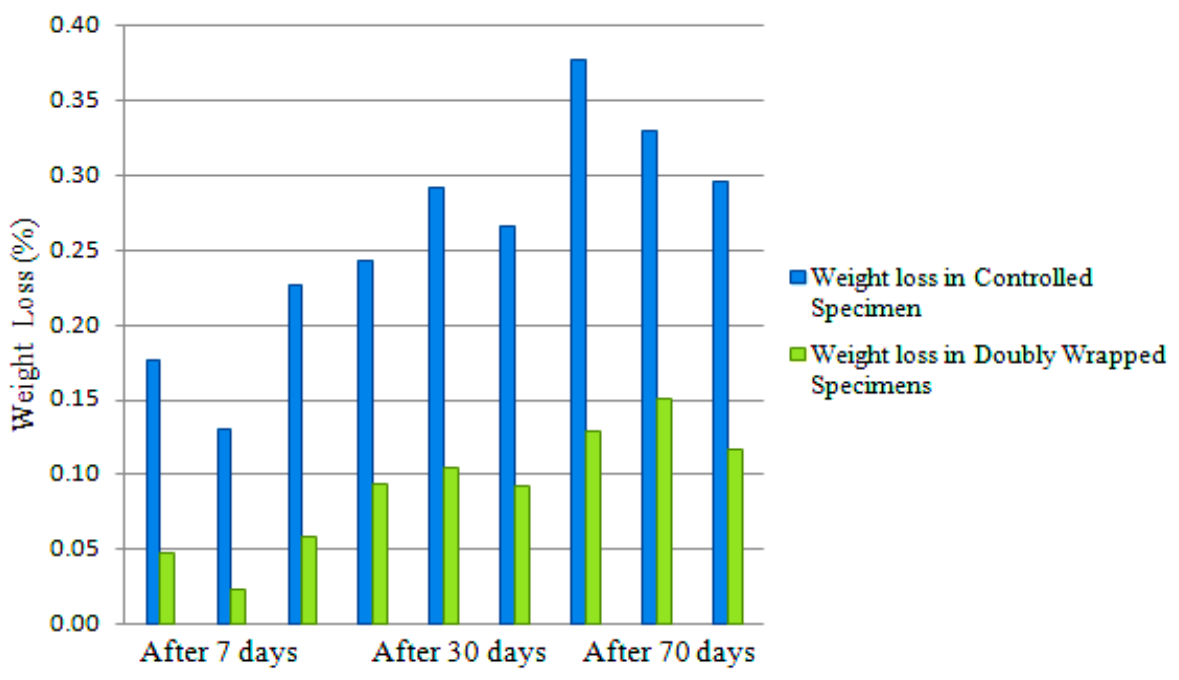

Figure 3. Weight loss in the acid resistance test.

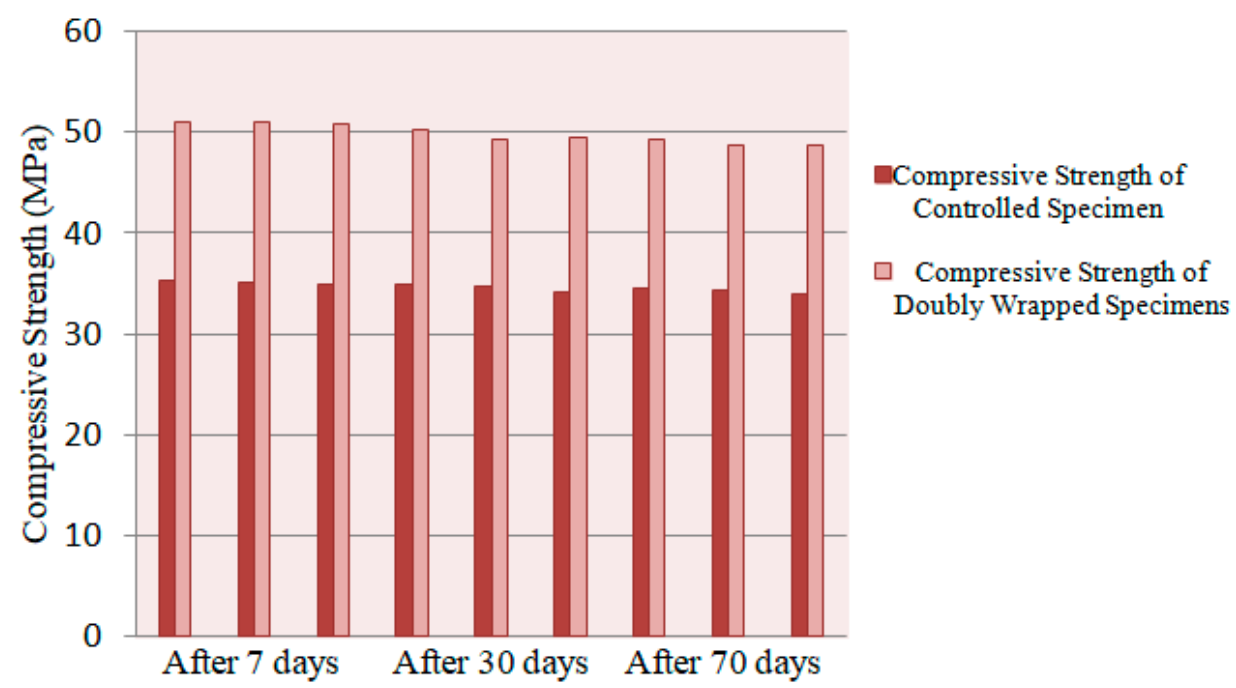

Figure 4. Compressive strength in the acid resistance test.

\subsubsection{Fire Resistance Test}

Concrete cubes were cast and cured for 28 days. In the fire resistant test, the initial weight of the concrete cube specimens were taken. The specimens were then kept in the oven at $200{ }^{\circ} \mathrm{C}$ for time intervals of $1 \mathrm{~h}$ and $2 \mathrm{~h}$, as shown in Figure 5. The final weight was taken for each specimen after a specific time interval. These specimens were tested for compressive strength. Comparisons were drawn between controlled specimens and aramid fiber double-wrapped specimens. Table 8 shows details of the fire resistance test after $1 \mathrm{~h}$. Accordingly, comparative charts were drawn for weight loss and compressive strength of each specimen, as shown in Figures 6 and 7. The remaining specimens were kept for $2 \mathrm{~h}$ in the oven at a temperature of $200{ }^{\circ} \mathrm{C}$. Results are tabulated in Table 9. Based on these results, compressive strength and weight loss are compared in Figures 8 and 9. 


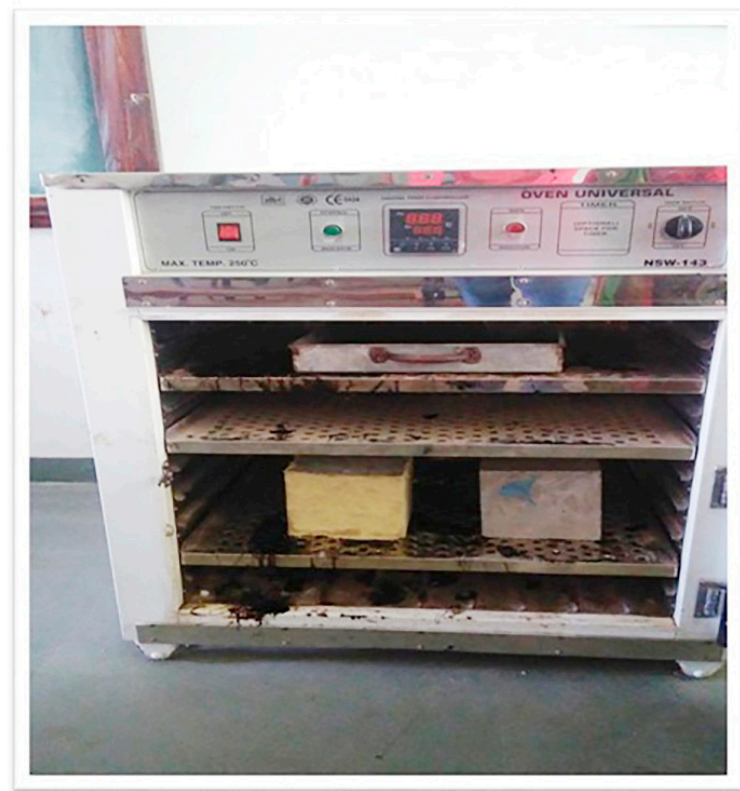

Figure 5. Fire resistance test.

Table 8. Fire resistance test at $200^{\circ} \mathrm{C}-1 \mathrm{~h}$.

\begin{tabular}{|c|c|c|c|c|c|c|}
\hline $\begin{array}{c}\text { Type of } \\
\text { Specimen }\end{array}$ & $\begin{array}{c}\text { Initial } \\
\text { Weight (g) }\end{array}$ & $\begin{array}{l}\text { Final Weight } \\
\text { after Heating (g) }\end{array}$ & $\begin{array}{l}\text { Weight Loss } \\
(\%)\end{array}$ & $\begin{array}{l}\text { Compressive } \\
\text { Load }(\mathbf{k N})\end{array}$ & $\begin{array}{l}\text { Compressive } \\
\text { Strength } \\
\left(\mathrm{N} / \mathrm{mm}^{2}\right)\end{array}$ & $\begin{array}{c}\text { Average } \\
\text { Compressive } \\
\text { Strength }\left(\mathrm{N} / \mathrm{mm}^{2}\right)\end{array}$ \\
\hline \multirow{3}{*}{$\begin{array}{l}\text { Controlled } \\
\text { specimen }\end{array}$} & 8565 & 8554 & 0.128 & 795 & 35.33 & \multirow{3}{*}{35.27} \\
\hline & 8530 & 8521 & 0.106 & 780 & 34.66 & \\
\hline & 8495 & 8482 & 0.153 & 806 & 35.82 & \\
\hline \multirow{3}{*}{$\begin{array}{c}\text { Aramid fiber } \\
\text { double-wrapped } \\
\text { specimen }\end{array}$} & 8611 & 8605 & 0.070 & 1194 & 53.06 & \multirow{3}{*}{53.01} \\
\hline & 8609 & 8601 & 0.093 & 1187 & 52.75 & \\
\hline & 8590 & 8582 & 0.093 & 1198 & 53.24 & \\
\hline
\end{tabular}

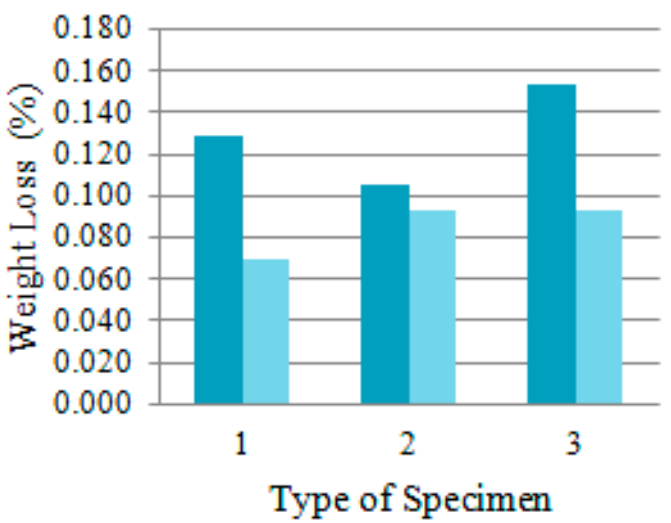

Controlled specimen

\section{Aramid fiber double} wrapped specimen

Figure 6. Weight loss at $200^{\circ} \mathrm{C}-1 \mathrm{~h}$.

Table 9. Fire resistance test at $200^{\circ} \mathrm{C}-2 \mathrm{~h}$.

\begin{tabular}{|c|c|c|c|c|c|c|}
\hline $\begin{array}{c}\text { Type of } \\
\text { Specimen }\end{array}$ & $\begin{array}{c}\text { Initial } \\
\text { Weight (g) }\end{array}$ & $\begin{array}{c}\text { Final } \\
\text { Weight after } \\
\text { Heating (g) }\end{array}$ & $\begin{array}{c}\text { Weight Loss } \\
(\%)\end{array}$ & $\begin{array}{l}\text { Compressive } \\
\text { Load }(k N)\end{array}$ & $\begin{array}{l}\text { Compressive } \\
\text { Strength } \\
\left(\mathrm{N} / \mathrm{mm}^{2}\right)\end{array}$ & $\begin{array}{c}\text { Average } \\
\text { Compress-ive } \\
\text { Strength }\left(\mathrm{N} / \mathrm{mm}^{2}\right)\end{array}$ \\
\hline \multirow{3}{*}{$\begin{array}{l}\text { Controlled } \\
\text { specimen }\end{array}$} & 8592 & 8581 & 0.1280 & 802 & 35.64 & \multirow{3}{*}{35.18} \\
\hline & 8553 & 8539 & 0.1637 & 785 & 34.88 & \\
\hline & 8568 & 8555 & 0.1517 & 788 & 35.02 & \\
\hline \multirow{3}{*}{$\begin{array}{c}\text { Aramid fiber } \\
\text { double-wrapped } \\
\text { specimen }\end{array}$} & 8605 & 8599 & 0.0697 & 1198 & 53.24 & \multirow{3}{*}{52.84} \\
\hline & 8595 & 8589 & 0.0698 & 1189 & 52.84 & \\
\hline & 8587 & 8580 & 0.0815 & 1180 & 52.44 & \\
\hline
\end{tabular}




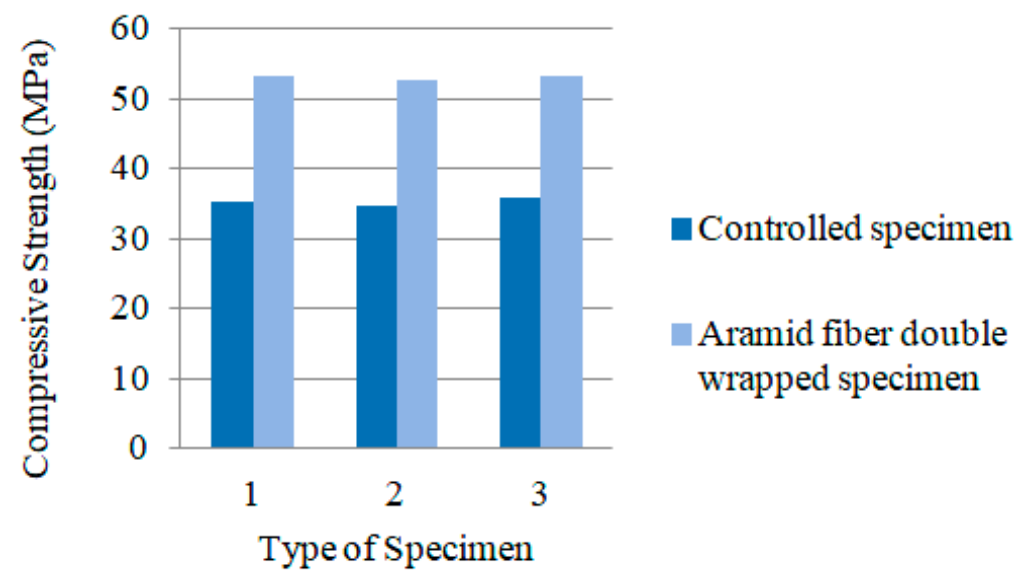

Figure 7. Compressive strength at $200^{\circ} \mathrm{C}-1 \mathrm{~h}$.

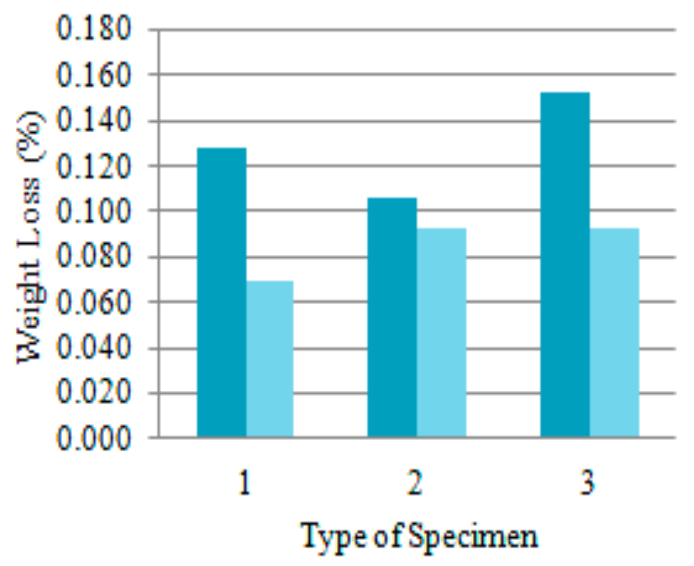

Controlled specimen

Aramid fiber double wrapped specimen

Figure 8. Weight loss at $200^{\circ} \mathrm{C}-2 \mathrm{~h}$.

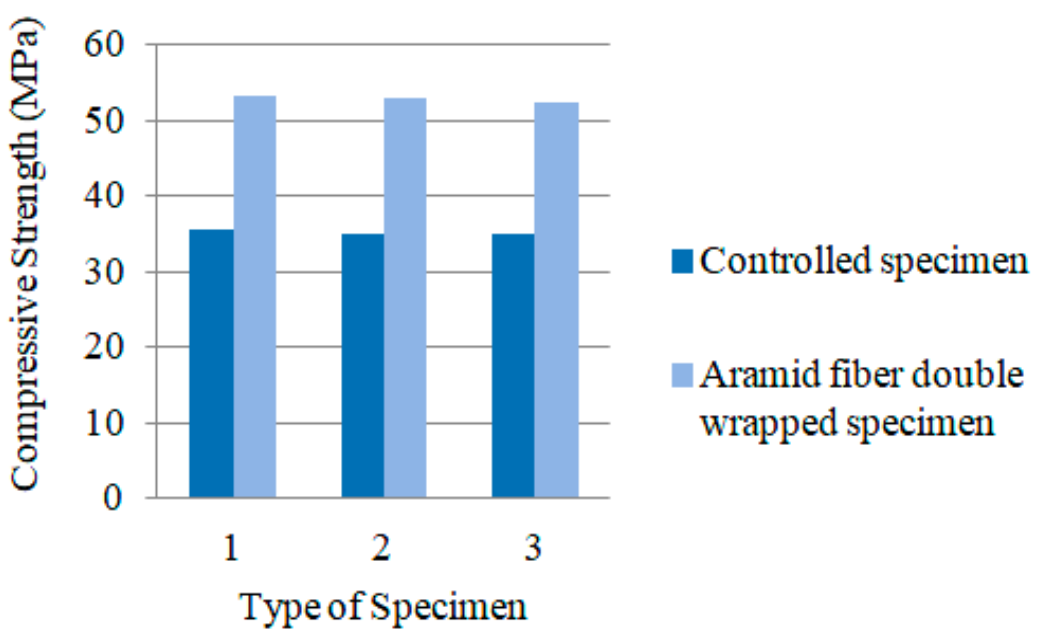

Figure 9. Compressive strength at $200^{\circ} \mathrm{C}-2 \mathrm{~h}$.

\section{Discussion}

A concrete cube specimen fails when the concrete is crushed. The maximum reading before the load gets reversed is taken as compressive load, and corresponding compressive strength is calculated. In the case of the acid resistance test, the average weight loss in the controlled specimens after 7 days, 30 days, and 70 days were $0.18 \%, 0.26 \%$, and $0.33 \%$, where average compressive strength was $35.06 \mathrm{MPa}$, 34.63 $\mathrm{MPa}$, and 34.27 MPa, respectively. In the case of the aramid fiber double-wrapped 
specimens, the average weight loss was $0.043 \%, 0.093 \%$, and $0.13 \%$, and average compressive strengths were $50.97 \mathrm{MPa}, 49.71 \mathrm{MPa}$, and $48.93 \mathrm{MPa}$, for 7 days, 30 days, and 70 days, respectively.

When specimens were subjected to the fire resistance test, average weight loss in the controlled specimen after $1 \mathrm{~h}$ of heating was $0.129 \%$ and average compressive strength was $35.27 \mathrm{MPa}$. In aramid-fiber double-wrapped specimens, average weight loss was just $0.085 \%$ and average compressive strength was $53.01 \mathrm{MPa}$. Figure 6 indicates that due to the double wrapping of aramid fiber, significant decreases in weight loss were found. Also, the compressive strength of the specimens increased when aramid-fiber wrapping was done, as shown in Figure 7. At $2 \mathrm{~h}$, weight loss and compressive strength were almost the same as at $1 \mathrm{~h}$, as shown in Figures 8 and 9 .

Modes of failure of the concrete cube before and after wrapping of aramid fiber are shown in Figure 10. These cubes are modeled in SAP 2000 NL for validation of results, as shown in Figure 11. It is observed that the maximum displacement of the controlled specimen is $0.210 \mathrm{~mm}$. For double-wrapped specimens, maximum displacement is $0.281 \mathrm{~mm}$. Due to confinement of fabric, load carrying capacity is increased, with an increase in displacement before failure. Maximum and minimum stresses in the controlled specimens are $47.43 \mathrm{MPa}$ and $32.49 \mathrm{MPa}$, respectively. After wrapping of specimen, maximum stress is increased to $67.02 \mathrm{MPa}$ and minimum stress is $32.56 \mathrm{MPa}$, as per SAP $2000 \mathrm{NL}$.

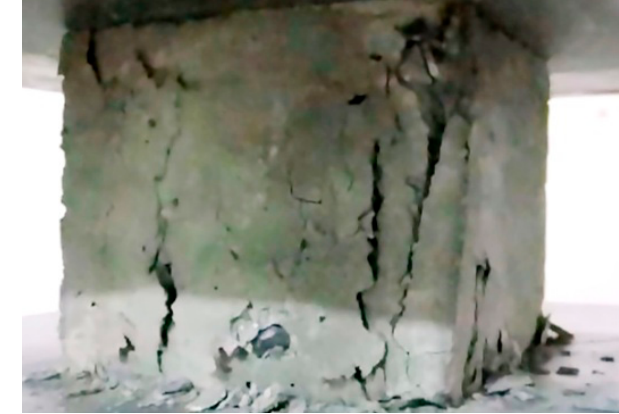

(a)

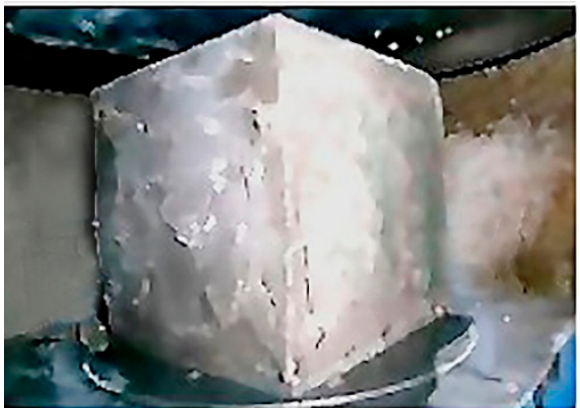

(b)

Figure 10. Concrete cube failure (a) without wrapping and (b) with double wrapping.

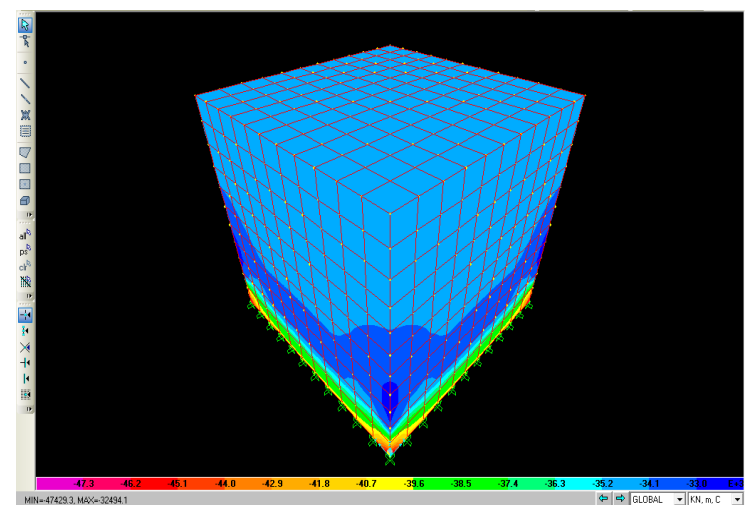

(a)

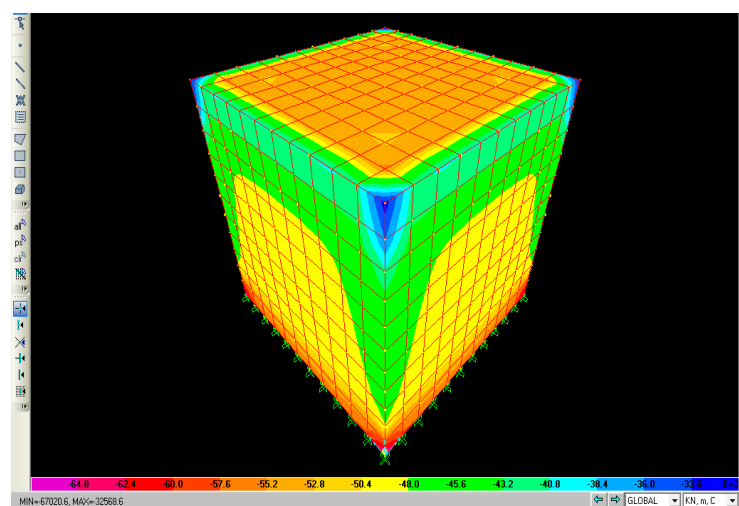

(b)

Figure 11. Concrete cube modeled in SAP 2000 NL (a) without wrapping and (b) with double wrapping.

\section{Conclusions}

From the experimental program, following conclusions are drawn:

1. In the acid resistance test, weight loss can be reduced by about $26 \%$ to $40 \%$ using double-wrapped aramid fiber.

2. Even after acid attack, compressive strength of specimens is increased by $142 \%$ at the end of 70 days by aramid-fiber wrapping. 
3. In the fire resistance test, weight loss of specimens can be reduced by $60 \%$ using aramid fiber.

4. With a rise in temperature at $200{ }^{\circ} \mathrm{C}$ for 1 or $2 \mathrm{~h}$, the compressive strength of specimens is increased by $150 \%$ when wrapped with aramid fiber.

5. Concrete cubes double-wrapped with aramid fiber show greater compressive strength and less weight loss when subjected to acid attack and thermal effects than the controlled cube specimens.

6. Aramid fiber can be used as a strengthening material for reinforced concrete elements subjected to compressive load, as it enhances durability and increases the life of the element.

7. This research paper is restricted to the wrapping of aramid fiber around concrete cubes in a double layer. The effect of a number of layers on the strengthening of a short column can be explored in further investigations.

Author Contributions: This research work is done by S.B.K. under the guidance of R.S.T. The joint efforts in terms of conceptualization, methodology and experimental investigations are made by the authors. Also, draft preparation, editing, and interpretations are done collectively.

Funding: This research received no external funding.

Acknowledgments: The authors are thankful to Amrutvahini College of Engineering, Sangamner, for the facilities provided.

Conflicts of Interest: The authors declare no conflict of interest.

\section{References}

1. Frigione, M.; Lettieri, M. Durability Issues and Challenges for Material Advancements in FRP Employed in the Construction Industry. Polymers 2018, 10, 247. [CrossRef]

2. Karbhari, V.M.; Chin, J.W.; Hunston, D.; Benmokrane, B.; Juska, T.; Morgan, R.; Lesko, J.J.; Sorathia, U.; Reynaud, D. Durability Gap Analysis for Fiber-Reinforced Polymer Composites in Civil Infrastructure. J. Compos. Constr. 2003, 7, 238-247. [CrossRef]

3. Nur Hajarul Falahi, A.H.; Sophia, C.A.; Mohammadreza, V.; Mahmoud, B.; Ali, F. Durability of Fibre Reinforced Polymer under Aggressive Environment and Severe Loading: A Review. Int. J. Appl. Eng. Res. 2017, 12, 12519-12533.

4. Fossetti, M.; Minafo, G. Strengthening of Masonry Columns with BFRCM or with Steel Wires: An Experimental Study. Fibers 2016, 4, 15. [CrossRef]

5. Anandakumar, R.; Seeni, A.; Selvamony, C.; Ravikumar, M.S. Durability Study on Basalt Fibre Reinforced Polymer (BFRP) Composites Wrapped Specimens for Retrofitting of RCC piles. Int. J. Eng. Res. Technol. 2014, 3, 315-320.

6. Hashim, M.H.M.; Sam, A.R.M.; Hussin, M.W. The future of external application of fiber reinforced polymer in civil infrastructure for tropical climates region. Int. J. Mech. Mater. Eng. 2011, 6, 147-159.

7. Choi, S.; Gartner, A.L.; Nathan, V.E.; Hamilton, H.R.; Douglas, E.P. Durability of Concrete Beams Externally Reinforced with CFRP Composites Exposed to Various Environments. J. Compos. Constr. 2012, 16, 10-20. [CrossRef]

8. Zaman, A.; Gutub, S.A.; Wafa, M.A. A review on FRP composites applications and durability concerns in the construction sector. J. Reinf. Plast. Compos. 2013, 32, 1966-1988. [CrossRef]

9. Zeng, Z.Z.; Ying, W.Z.; Li, L.S.; Feng, X.; Jia, D. Progress in Durability Study of FRP Materials. In Proceedings of the International Conference on Durability of Concrete Structures, Shenzhen, China, 30 June-1 July 2016.

10. Byars, E.A.; Waldron, P.; Dejke, V.; Demis, S.; Heddadin, S. Durability of FRP in concrete-Deterioration mechanisms. Int. J. Mater. Prod. Technol. 2003, 19. [CrossRef]

11. Hamad, R.J.A.; Megat, J.M.A.; Haddad, R.H. Mechanical properties and bond characteristics of different fiber reinforced polymer rebars at elevated temperatures. Constr. Build. Mater. 2017, 142, 521-535. [CrossRef]

12. Hawileh, R.A.; Abu-Obeidah, A.; Abdalla, J.A.; AlTamimi, A. Temperature effect on the mechanical properties of carbon, glass, and carbon-glass FRP laminates. Constr. Build. Mater. 2015, 75, 342-348. [CrossRef]

13. Chen, X.; Zhou, Y. Technical Textiles for Ballistic Protection. Handbook of Technical Textiles, 2nd ed.; Technical Textile Applications; Woodhead Publishing: Sawston/Cambridge, UK, 2016; Volume 2, pp. 169-192. ISBN 9781782424888. 
14. Jassal, M.; Ghosh, A. Aramid fibers-An overview. Indian J. Fiber Textile Res. 2002, 27, 290-306.

15. Granata, P.J.; Parvin, A. An experimental study on Kevlar strengthening of beam column connection. Compos. Struct. 2001, 52, 163-171. [CrossRef]

16. Pereira, M.J.; Revilock, D.M. Ballistic impact response of Kevlar 49 and Zylon under conditions representing jet engine fan containment. J. Aerospace Eng. 2009, 22, 240-249. [CrossRef] 